\title{
Surgical hand preparation without rinsing: influence of antiseptic agent on bacteriological contamination
}

\begin{abstract}
The aim of this study was verify the efficacy and influence of antiseptic agents on the degree of bacteriological contamination of the hands, after pre-surgical hygiene without rinsing, using the products recommended by WHO. Samples were collected from 22 volunteers. The level of bacterial contamination was obtained from finger and thumb of the dominant hand of each participant before and after hygiene. The groups were distributed according to the formulations recommended by the World Health Organization (WHO): 1-who ethyl-hygiene with whom formulation the basis of ethyl alcohol; 2-who isopropyl-hygiene with who formulations of isopropyl alcohol. Both groups promoted significant reduction in the degree of bacteriological contamination after the hygiene of the hands (Anova/Tukey; F-crit=4.3512, $\mathrm{f}=5.5806, \mathrm{p}=0.02840$ ). The WHO isopropyl group provided a reduction of the bacteriological load of the order of $53.02 \%$, while the ethyl OMS obtained the value of $39.45 \%$, statistically different values between each other (Anova/Tukey; $\mathrm{F}$-crit $=4.3512 ; \mathrm{f}=78.218 ; \mathrm{p}=0.0111$ ). The surgical hand hygiene using the WHO formulations were effective in reducing microorganisms. Isopropyl alcohol showed better results than ethyl alcohol in surgical hand hygiene without rinsing.
\end{abstract}

Keywords: hand disinfection, isopropyl alcohol, ethyl alcohol, contamination

\author{
Volume I0 Issue I - 2019
}

\author{
Márcio Romeu Pinheiro De Lima,' Altamir \\ Oliveira De Figueiredo Filho,' Jessica Silva \\ Peixoto Bem,' Melissa Santos Da Silva \\ Simões,' Eliana Freire Dos Santos,' Ingrid \\ Melo Schüler Arreguy,' Carlos Roberto \\ Weber Sobrinho, ${ }^{2}$ Fábio Barbosa De Souza ${ }^{3}$ \\ 'Dental School, Federal University of Pernambuco, Brazil \\ ${ }^{2}$ Department of Tropical Medicine, Federal University of \\ Pernambuco, Brazil \\ ${ }^{3}$ Department of Prosthodontics and Oral Facial Surgery, Federal \\ University of Pernambuco, Brazil
}

\begin{abstract}
Correspondence: Fábio Barbosa de Souza, Federal University of Pernambuco, Department of Prosthodontics and Oral Facial Surgery, Av. Prof. Moraes Rego s/n, Cidade Universitária, RecifePE, CEP: 50670-90 I, Brazil,Tel +55-8I-2 I 26-8830, +55-8I-99748237; Fax +55-8I-2I 26-8344, Email fabiobdsouza@gmail.com
\end{abstract}

Received: February 20, 2019 | Published: February 27, 2019

\section{Introduction}

Hospital infections represent a global public health problem and are a risk to users of hospital services. Postoperative infections, currently referred to as surgical site infections (SSI), account for a significant proportion of all of these hospital infections. ${ }^{1}$ Among the practices for the prevention of SSI, degermation of the hands and forearms of the surgical team, as a preoperative preparation, had its origin when Ignaz Semmelweis, in 1847, advocated the use of germicide for washing hands before examining the parturient. ${ }^{2,3}$ The effect of skin antisepsis on reducing surgical site infection has been historically demonstrated by Joseph Lister (1827-1912). At that time, surgical gloves were not yet available, which made proper antisepsis of the patient's skin and of the hands of the surgeon even more important. ${ }^{4}$ The hands act as a reservoir of microorganisms, considered the main route of transmission of pathologies, presenting the highest index of hospital infection. Even with the use of gloves, micro perforations may occur due to their use, in addition to contamination of the hands during their withdrawal. ${ }^{5}$ Human skin is colonized by bacteria, whose density varies according to the sites. The species found in the hands are classified into two groups: resident microbiome and transient microbiome. ${ }^{6}$ The bacteria of the transient microbiome, despite having greater pathogenicity, appear to be removed by hand hygiene, as they are more superficially and poorly adhered to the skin. ${ }^{7}$ The hand hygiene activity has been associated with a significant reduction of hospital infections. Evidence from experimental and non-experimental studies is fairly consistent with the hypothesis that handwashing is a causal association with reduced risk of infection..$^{6-9}$ Care with the surgical degermation of the hands and forearms is justified by the perforation rate of the gloves at the end of the surgery of $18 \%$, and in more than $35 \%$ of the cases these perforations are not perceived by the surgeons, besides the fact that some gloves are permeable to bactéria. ${ }^{10}$ The purpose of pre-surgical antisepsis is to reduce the resident and transient microbial load of the hands, thus reducing the introduction of microorganisms into the surgical site1. It is fundamental for the practice of hygiene, especially when referring to a health professional, who, in order to perform any type of surgical procedure, should use antiseptic solutions because they promote a greater reduction of microorganisms. ${ }^{6}$ Not necessarily this technique requires soap and water to be effective. Clinical trials have demonstrated the effectiveness of techniques without rinsing, in which alcohol-based solutions are used for pre-surgical hygiene. ${ }^{6,9,11,12}$ To help countries and health facilities adopt alcohol-based products as a gold standard for hand hygiene, the World Health Organization (WHO) has developed formulations for local preparation as an alternative when appropriate commercial products are not available or are very expensive. These formulations have presented excellent tolerability, good acceptance, low cost and high importance for the clinical effect. ${ }^{11}$ The WHO proposes two possibilities of manipulation, being one based on ethyl alcohol and another one based on isopropyl alcohol. Considering that these active principles provide different potentials for reducing microbial load, ${ }^{13}$ this study aimed to verify the efficacy and influence of antiseptic agents on the degree of bacteriological contamination of the hands, after pre-surgical hygiene without rinsing, using the products recommended by WHO.

\section{Methods}

This is an experimental, field and laboratory research, whose volunteers were students enrolled in the dental school of the Federal University of Pernambuco - Brazil, who provided dental care in school clinics. The exclusion criteria were: age less than 18 years; pregnancy; cuts, scratches or any change in the skin of the hands; use of soap or antiseptic agent for less than two hours prior to collection. Nails should be short and clean. All volunteers signed a free and informed consent form. The study was submitted to the Ethics Committee in Research with Human Beings of the Federal University of Pernambuco, approved under the no. 1.541.110.

A total of 22 volunteer students participated in the research, which were randomly distributed into two groups (11 students each) according to the hand hygiene product: 
1. WHO ETHYL - pre-surgical hygiene with a WHO-recommended formulation based on ethyl alcohol.

2. WHO ISOPROPYL - pre-surgical hygiene with a formulation recommended by the WHO based on isopropyl alcohol. Table 1 shows the composition of these products, which were produced in a handling pharmacy (Phormula Ativa $\left.{ }^{\circledR}\right)$.

Table I Composition of the formulations indicated by WHO

\begin{tabular}{ll}
\hline Formulation - Group & composition \\
\hline \multirow{3}{*}{1} & Ethanol $80 \% v / v$ \\
& Glycerin $1,45 \% v / v$ \\
& Hydrogen peroxide $(\mathrm{H} 2 \mathrm{O} 2) 0,125 \% v / v$ \\
& Isopropyl alcohol $75 \% v / v$ \\
& Glycerin $1,45 \% v / v$ \\
& Hydrogen peroxide $\left(\mathrm{H}_{2} \mathrm{O}_{2}\right) 0,125 \% v / v$
\end{tabular}

The hand hygiene techniques carried out in the study followed the protocol and recommendations of the World Health Organization (WHO, 2013). Before hand antisepsis, participants were instructed to remove props (rings, watches, bracelets). The hand hygiene protocol was reviewed with each student prior to the survey and accompanied by the previously trained examiner. Each preparation of hands had 2 minutes and 20 seconds duration. All the collections were performed in the afternoon shift, before the beginning of clinical care. For each participant, the collection resulted in 4 biological samples of the dominant hand (thumb and Indicator, before and after hand hygiene), resulting in 44 samples per group. Initially, students were instructed to hold the test tubes (one for the thumb and one for the gauge) by positioning said fingers to completely occlude their opening and shaking the $5 \mathrm{~mL}$ of sterile distilled water present inside the tube so that this contact with the skin of the palmar region. For all groups, the contact time was 30 seconds. After hand hygiene, two other test tubes containing distilled water were provided for collection of microorganisms, repeating the previous step. The tubes were identified, packed in thermal containers until the end of all the collections and immediately transported to the Laboratory of Microbiology of the Department of Tropical Medicine for the processing of the sample. An aliquot of $1 \mathrm{ml}$ of each sample was subjected to serial dilutions with titration of 1:10 and 1: 100. Then, by means of the Pour Plate technique, samples were incubated for $48 \mathrm{~h}$ at $37^{\circ} \mathrm{C}$ in Difco ${ }^{\mathrm{TM}}$ Mueller Hinton Agar. After the incubation period, the plates were read by a trained evaluator, assisted by a stereomicroscope under reflected light. The result in colony forming units (CFU) was multiplied by the correction factor and divided by the opening area of the test tube to obtain the $\mathrm{CFU} / \mathrm{cm}^{2}$ value, taking into account the dilution and the opening area of each tube. For the evaluation of the effectiveness of the products for pre-surgical hygiene in each group, the values were grouped by volunteers, based on the average obtained between the counts of the thumb and the indicator of the same individual. Thus, each group had $\mathrm{n}=22$, with 11 means obtained from collections performed before the hygiene and 11 averages obtained from collections performed after the hygiene. The data was typed in an Excel spreadsheet and analyzed in the Assistat version 7.7 beta program. The Mann Whitney test was used to verify differences between thumb surfaces and Indicators, as well as to analyze comparatively the logarithms of the averages obtained before and after the hygiene. To compare the reduction of the number of bacteria was used the ANOVA+Tukey Test. Statistical significance was considered when $\mathrm{p}<0.05$.

\section{Results}

The amount of microorganisms on the palmar surface of the thumb and forefinger, prior to hand hygiene, varied from $1,327 \times 10^{3}$ a $1,0619 \times 10^{4} \mathrm{CFU} / \mathrm{cm}^{2}$. The average obtained in the analyzes of the thumbs $\left(5,671 \times 10^{3} \mathrm{CFU} / \mathrm{cm}^{2}\right)$ was slightly higher than the indicators $\left(4,505 \times 10^{3} \mathrm{CFU} / \mathrm{cm}^{2}\right)$. However, when performing analysis of variance (ANOVA) and applying the Tukey test for the logarithms of the means, no statistically significant difference was observed (F-crit $=$ $4.0728, \mathrm{~F}=3.418, \mathrm{p}=0.0714)$. For the evaluation of the effectiveness of the products for antiseptic friction in each group, the values were grouped by volunteer, from the average obtained between the counts of the thumb and indicator of the same individual. Thus, each group had $\mathrm{n}=22$, with 11 means obtained from collections performed before the hygiene and 11 averages obtained from collections performed after the hygiene. Table 2 shows the values obtained. In all groups, a reduction in the amount of $\mathrm{CFU} / \mathrm{cm}^{2}$ post-hygiene could be observed.

Table 2 Mean and standard deviation $\left( \pm\right.$ ) of the number of $\mathrm{CFU} / \mathrm{cm}^{2}$ and the decimal $\log$ of the number of $\mathrm{CFU} / \mathrm{cm}^{2}$ of the palmar surface of the fingers of volunteers according to the study group, before and after the hygiene

\begin{tabular}{llll}
\hline Variable & & WHO Ethyl & WHO Isopropyl \\
\hline \multirow{3}{*}{ BFC/cm ${ }^{2}$} & $4.605,7924$ & $5.571,1987$ \\
& & $\pm 2.307,2966$ & $\pm 2.572,1216$ \\
& After & $2.815,7683$ & $2.896,21883$ \\
& & $\pm 1.467,83627$ & $\pm 2.289,48534$ \\
Decimal Log & 36,159 & 37,085 \\
& & $\pm 0,2103$ & $\pm 0,1847$ \\
& \multirow{2}{*}{ After } & 33,957 & 33,628 \\
& & $\pm 0,2265$ & $\pm 0,2927$ \\
\hline
\end{tabular}

Both products recommended by the WHO promoted a significant reduction in the degree of bacteriological contamination after hand hygiene. Thus, when analyzing the logarithms of the averages obtained before and after the hygiene, a statistically significant difference was observed after ANOVA / Tukey tests (F-crit $=4.3512$, $\mathrm{F}=5.5806, \mathrm{p}=0.0284$ ). Figure 1 shows the percentage of reduction of microbial load after sanitization. It was observed that, when applying the Variance Analysis to one factor, there was a statistically significant difference between the groups ( $\mathrm{F}$-crit=4.3512; $\mathrm{F}=78.218 ; \mathrm{p}=0.0111$ ). The Tukey test, at the $5 \%$ probability level, revealed that the means of the percentages of each group were statistically different from each other.

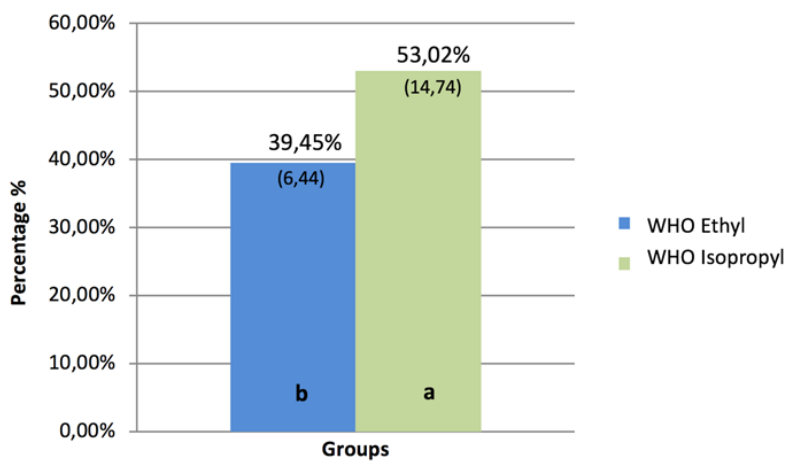

Figure 1 Percentage reduction of the microbial load of the palmar surface of the fingers of volunteers after the hygiene, according to the study group. The standard deviation values are represented in brackets. Different letters represent statistical difference in the comparison of means between groups. 


\section{Discussion}

The hands are the main tools of professionals who work in the health services and are always in contact with the most varied surfaces. Thus, careful and frequent hand hygiene promotes patient safety in these services, especially at surgical times. In this study, it was observed that the surfaces of thumbs and indicators did not show a significant contamination difference, regardless of the product used, after the Mann Whitney test for the logarithms of the means $(Z=1.96$, $\mathrm{p}>0.05$ ). A similar result was found by Ferreira. ${ }^{14}$ Since, from the functional point of view, these are the most requested fingers, similar results were already expected. In spite of this, in another study it was possible to observe a mean microbial load of thumbs and indicators with different values. ${ }^{15}$ These results are understandable, since the total count of bacteria in the hands of health professionals can change from person to person, which may interfere with the results. ${ }^{5}$ The practice of preoperative handwashing arose during the fight against puerperal fever in the late 1840s. Only recently have aqueous solutions been introduced to perform this technique. ${ }^{16} \mathrm{WHO}$ experts recommend that agents used for surgical hand preparation should: significantly reduce micro-organisms in intact skin; contain a non-irritating antimicrobial preparation; have broad spectrum activity; and be fast-paced and persistent. Therefore, surgical hand preparation products should eliminate transient flora and significantly reduce resident flora at the start of a surgical procedure, and maintain microbial release of the hands below the baseline until the end of the procedure. ${ }^{11}$ There is scientific evidence supporting the safety of alcoholic preparations for surgical hand antisepsis ${ }^{17}$ and the World Health Organization has published WHO Guidelines on Hand Hygiene in Health Care where alcohol is indicated as the best option for pre-surgical hands hygiene. ${ }^{11}$

In this study, the results showed a significant reduction (Table 2) after the pre-surgical hygiene with the solutions recommended by the WHO. In addition to the high antimicrobial effectiveness resulting from its ability to denature proteins, ${ }^{11}$ the alcohols are easier to apply, less skin damage, time saving, low toxicity, ease of acquisition and use without the need for prior application of soap and water. ${ }^{18}$ Alcohols have excellent in vitro germicidal activity against Gram-positive and Gram-negative bacteria including the multiresistant microorganisms, and they also have virucide characteristics. However, these antiseptics have low activity against spores, protozoal oocysts and non-enveloped viruses. ${ }^{11,19,20}$ Therefore, concentrations of ethyl alcohol with $80 \%$ and isopropyl alcohol with $75 \%$ are within the range considered to be effective for surgical disinfection of the hands. ${ }^{21}$

Although both formulations proved to be effective, it was possible to observe that the WHO Isopropyl Group showed a greater reduction of the microbial load of the palmar region of the hands, when compared with the WHO Ethyl Group. In the comparison of efficacy between the formulations, the Kampf \& Ostermeyer ${ }^{13}$ experiment presented similar results, showing a reduction between $2.43 \pm 1.10 \log 10$ for the WHO Ethyl formulation and a reduction between $2.72 \pm 1.06 \log 10$ for the formulation WHO Isopropyl. Although ethyl alcohol and isopropyl alcohol have activity against bacteria in the vegetative form, enveloped viruses (eg influenza, hepatitis B and C, and AIDS viruses), mycobacteria and fungi, ${ }^{22}$ in general, isopropyl alcohol is considered more effective against bacteria, whereas ethyl alcohol is more potent against viruses. ${ }^{23}$ This could justify the results found, since the methodological approach was a bacteriological quantitative analysis.

Logistical, economic, safety, cultural and religious factors were carefully considered by WHO before recommending such formulations for use throughout the world. The components of these formulations were selected based on evidence that showed intrinsic advantages of rapid and broad-spectrum action, with minimal risk of generating resistance to antimicrobial agents, as well as economic benefits, reducing annual costs of hand hygiene, representing around $1 \%$ of the extra costs generated by healthcare-associated infections. ${ }^{11}$

The negative action of alcohol-based disinfectants has been debated, due to the possibility of drying the skin caused by dehydration. Frequent use of alcohol can cause skin dryness. However, this effect can be minimized or eliminated provided that emollients, humectants or other conditioning agents are added to the formulation. ${ }^{24}$ What can happen with the addition of glycerin or other skin moisturizing agent. ${ }^{25}$ Studies have shown that when emollient substances are added, alcohol has less hand dryness than the simple use of antimicrobial soaps. ${ }^{26}$ Glycerin is present in the two formulations recommended by WHO, used in this study, which consequently may have reduced this alcohol drying effect. However, the addition of emollients such as glycerin has been of concern since it was possible to observe a significant reduction of the residual antimicrobial potential of alcohol-based substances (ethyl, isopropyl and n-propyl) associated with glycerol after use in friction pre-surgical. Still use of alcohols for hand hygiene has clear advantages over washing with soap and wate. ${ }^{25}$

The irritant potential of alcohols appears to be quite low, but even formulations containing emollients well tolerated by health professionals can cause a burning sensation if applied to continued skin solutions - such as cuts and abrasions. Cases of dermatitis or urticarial contact syndromes triggered by alcohol or by additive substances added to the compounds also occur. ${ }^{27}$ Alcohols are also flammable and extremely susceptible to the environment conditions, consisting of a volatile substance. In view of these characteristics, care must be taken in the handling and packaging of alcohol-based antiseptics. ${ }^{26}$

The adherence of health professionals to the practice of hand hygiene can be significantly influenced by several factors, and their identification constitutes an important strategy for the prevention of infections. Thus, preparations containing substances containing alcohol in their composition represent a promising alternative in the control of microbial spread through the hands..$^{28}$ In this research, all laboratory parameters were controlled to prevent the influence of external biases, providing scientific information about the products used that presents great potential for use in the field of health sciences. However, a prospective analysis is suggested, with the purpose of evaluating the effectiveness of pre-surgical hygiene over time, as well as conducting a qualitative research, through the identification of the microorganisms involved in the hygiene process.

\section{Conclusion}

The products studied were effective for the hand pre-surgical hygiene, promoting a significant reduction of the microbial load in the palmar region with the products recommended by the WHO. It was verified that the antiseptic agent exerted influence on the degree of bacteriological contamination of the hands, demonstrating superiority of the isopropyl alcohol in relation to the ethyl alcohol in the presurgical hygiene without rinsing.

\section{Acknowledgments}

None. 


\section{Conflicts of interest}

The authors declare that there are no conflicts of interest.

\section{References}

1. Adams AB. Surgical Hand Antisepsis: Where We Have Been and Where We Are Today. Perioperative Nursing Clinics. 2010;5(4):443-448.

2. Fernandes AT. A medicina e as bases da civilização Ocidental. In Fernandes AT, editor. Infecção hospitalar e suas interfaces na área da saúde. São Paulo: Atheneu; 2000;91-113.

3. Hobson DW, Woller W, Anderson L, et al. Development and evolution of a new alcohol-based surgical hand scrub formulation with persistent anti microbial characteristics and brushless application. Am J Infect Control. 1998;26(5):507-512.

4. Widmer AF, Rotter M, Voss A, et al. Surgical hand pre-paration: stateof-the-art. J Hosp Infect. 2010;74(2):112-122.

5. Custódio J, Alves JF, Silva FM, et al. Avaliação microbio-lógica das mãos de profissionais da saúde de um hospital particular de Itumbiara, Goiás. Rev Ciênc Méd. 2009;18(1):7-11.

6. Silva DG, Lima PC, Nunes MRCM, et al. Comparison Between Two Methods of Preoperative Antisepsis of Hands in Oral Surgery. Rev Cir Traumatol Buco-Maxilo-Fac. 2011;11(2):45-54.

7. Kawagoe JY. Higiene das mãos: comparação da eficácia antimicrobiana do álcool - formulação gel e líquida - nas mãos com matéria orgânica. São Paulo: Universidade de São Paulo, Escola de Enfermagem; 2004 $132 \mathrm{p}$.

8. Larson E. Skin hygiene and infection prevention: more of the same or different approaches. Clin Infect Dis. 1999;29(5):1287-1294.

9. Goulart DG, Assis EA, De-Souza MT. Microbiological evaluation of preoperative antisepsis of hands. Rev Cir Traumatol Buco-Maxilo-Fac. 2011;11(3):103-112.

10. Parienti JJ, Thibon P, Heller R, et al. Hand rubbing with an aqueous alcoholic soluti on vs traditional surgical hand-scrubbing and 30-day surgical site infection rates: a randomized equivalence study. JAMA 2002;288(6):722-727.

11. World Health Organization (WHO). WHO guidelines on hand hygiene in health care. First global patient safety challenge. Clean care is safe care. 2009.

12. Cunha ER. Eficácia de três métodos de degermação das mãos utilizando gluconato declorexidina degermante (GCH 2\%). Rev Esc Enferm USP. 2011;45(6):1440-1445

13. Kampf G, Ostermeyer C. World Health Organization-recommended hand-rub formulations do not meet European efficacy requirements for surgical hand disinfection in five minutes. Journal of Hospital Infection. 2011;78:123-127.

14. Ferreira GMA. Avaliação microbiológica comparativa entre diferentes produtos para fricção antisséptica das mãos. Monografia apresentada à disciplina de Trabalho de Conclusão de Curso 2 como parte dos requisitos para conclusão do Curso de Graduação em Odontologia do Centro de Ciências da Saúde da Universidade Federal de Pernambuco. Recife-PE. 2016:1-26.

15. Dotto PP, Zucuni CP, Antes GB, et al. Eficácia de dois métodos de degermação das mãos. Rev Cir Traumatol Buco-Maxilo-Fac. 2015;15(3):7-14.

16. Lung DC, Man JHK, Tang THC, et al. Surgical hand-washing. Ann Coll Surg H.K. 2004;8:71-75.

17. Kawagoe JY. Trends and challenges of surgical hand preparation. Rev SOBECC, São Paulo. 2016;21(4):217-222.

18. Rosa GRL, Leite MC. Efetividade de um produto a base de álcool gel na antissepsia das mãos. Monografia apresentada como parte dos requisitos para obtenção do diploma de farmacêutico pelo curso de farmácia da faculdade de Pindamonhangaba. Pindamonhangaba. 2010:1-55.

19. Guideline for hand-Boyce JM, Pittet D. Guideline for Hand Hygiene in Health-Care Settings. Recommendations of the Healthcare Infection Control Practices Advisory Committee and the HICPAC/SHEA/APIC IDSA Hand Hygiene Task Force. Society for Healthcare Epidemiology of America/Association for Professionals in Infection Control/Infectious Diseases Society of America. MMWR Recomm Rep. 2002;23:S4-S41.

20. Kampf G, Hollingsworth A. Validity of the four European test strains of prEN 12054 for the determination of comprehensive bactericidal activity of an alcohol-based hand rub. Journal of Hospital Infection. 2003;55(3):226-231.

21. Kampf G, Kramer A. Epidemiologic Background of Hand Hygiene and Evaluation of the Most Important Agents for Scrubs and Rubs. Clin Microbial Rev. 2004;17(4):863-893

22. Yosef A Alcohols. Disinfection, Sterilization, and Preservation. $5^{\text {th }}$ ed 2000;229-253.

23. Rotter ML. Hand washing, hand disinfection and skin disinfection. In Wenzel RP, ed. Williams \& Wilkins, Baltimore. 1997;691-709.

24. Ramos TCF. Avaliação da contaminação microbiana das mãos de profissionais de saúde em um hospital escola da rede pública de Feira de Santana. Feira de Santana - BA. 2012:1-25

25. Suchomel M, Rotter M, Weinlich M, et al. Glycerol significantly decreases the three hour efficacy of alcohol-based surgical hand rubs. Journal of Hospital Infection. 2013;83(4):284-287.

26. Maciel MA. Lavagem pré-cirúrgica das mãos: uma revisão de literatura. Monografia de conclusão do componente curricular MED-B60, do currículo médico da Faculdade de Medicina da Bahia (FMB) da Universidade Federal da Bahia (UFBA). Salvador- BA. 2012:1-50

27. McCormick R. Review of Handwashing Guidelines Segunda Edição. Philadelphia: W.B Saunders Company. 2001.

28. Ezaias GM. Estratégia multimodal na promoção da higiene das mãos: atributos para aceitação e tolerância das preparações alcoólicas. Dissertação de mestrado, apresentada à escola de enfermagem de Ribeirão Preto/USP. Ribeirão Preto. 2012:1-112. 